\title{
Methyltransferase Activity of an Iridium Center with Methylpyridinium as Methylene Source
}

\author{
Ralte Lalrempuia, Helge Müller-Bunz, Martin Albrecht*
}

The selective transfer of a methyl or alkyl group to an unactivated carbon center is of prevalent synthetic and biochemical interest. ${ }^{[1]}$ In biological systems, methylation typically involves transferring a $\mathrm{CH}_{3}$ group from a sulfide carrier such as S-adenosylmethionine (AdoMet) as mild methylating agent, ${ }^{[2]}$ using a cobalamin cofactor as $\mathrm{CH}_{3}$-donor. ${ }^{[3]}$ While most AdoMet-type transferases deliver a methyl group, recent work showed that certain enzymes rather utilize a methylene unit $\left(\mathrm{CH}_{2}\right)$ for substrate alkylation. ${ }^{[4]}$

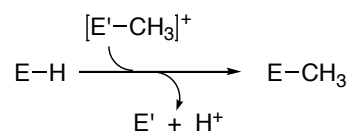

Scheme 1. Generic methyl transfer, E' = S, N for mild transfer, E' = $\mathrm{O}$, halide, for harsh transfer.

Synthetic mimics of methyltransferases have been developed for the transfer of a methyl group from sulfonium or iminium salts to a heteroatom receptor $(\mathrm{E}=\mathrm{N}, \mathrm{O}, \mathrm{P}, \mathrm{S}$; Scheme 1$) .{ }^{[5]}$ Non-enzymatic mimicking of alkyl group transfer from sulfur or nitrogen to carbon and formation of a new $\mathrm{C}-\mathrm{C}$ bond, as observed for example in DNA methylation, ${ }^{[6]}$ is very rare. ${ }^{[7]} \mathrm{A}$ key challenge is the $\mathrm{E}^{\prime}-\mathrm{C}_{\mathrm{Me}}$ bond cleavage from the carrier system $\left(E^{\prime}=S, N\right)$, which is required to activate the transferable group. ${ }^{[8]}$ Notably, selective $\mathrm{C}-\mathrm{N}$ bond cleavage has been observed using an imidazolium-type source for alkyl group release under mild conditions in N-heterocyclic carbene (NHC) ruthenium complexes, ${ }^{[9]}$ though no controlled transfer to a substrate was noticed. Here we report on an iridium complex that facilitates the selective transfer of a methylene group from a pyridinium fragment to an aryl unit with concomitant activation of a nitrile solvent molecule. This process involves $\mathrm{C}-\mathrm{N}$ bond cleavage and double $\mathrm{C}\left(\mathrm{sp}^{2}\right)-\mathrm{C}\left(\mathrm{sp}^{3}\right)$ bond formation within the iridium coordination sphere. This complex thus represents a unique functional analogue of methyltransferases and enables new synthetic transformations.

[*] Dr. R. Lalrempuia, Dr. H. Müller-Bunz, Prof. Dr. M. Albrecht School of Chemistry \& Chemical Biology

University College Dublin

Belfield, Dublin 4, Ireland

Fax: (+)3531716 2501

E-mail: martin.albrecht@ucd.ie

[**] We thank J. Muldoon and Y. Ortin for NMR measurements. This work has been financially supported by the European Research Council (ERC-StG 208561) and by Science Foundation Ireland.

Supporting information for this article is available on the WWW under http://www.angewandte.org or from the author.

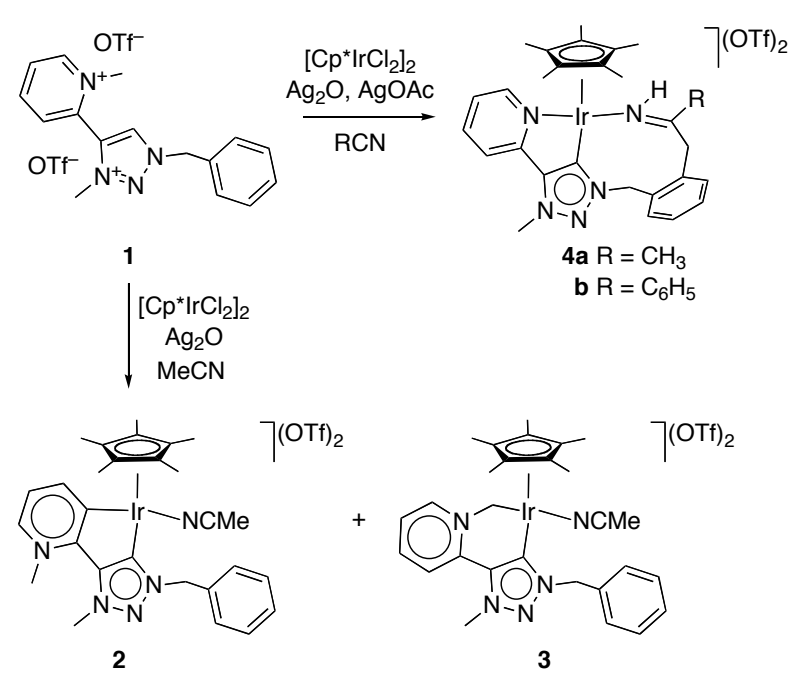

Scheme 2. Synthesis of complex 4 via methylene transfer and RCN activation.

Previous studies in our laboratories have shown that $\left[\operatorname{Ir}\left(\mathrm{Cp}^{*}\right) \mathrm{Cl}_{2}\right]_{2}$ reacts in the presence of $\mathrm{Ag}_{2} \mathrm{O}$ with the pyridiniumtriazolium salt 1 either via pyridinium $\mathrm{C}\left(\mathrm{sp}^{2}\right)-\mathrm{H}$ bond activation or via exocyclic $\mathrm{C}-\mathrm{H}$ bond activation to give $\mathbf{2}$ and $\mathbf{3}$, respectively (Scheme 2). ${ }^{[10]}$ If acetate is added to the reaction mixture either as AgOAc or NaOAc, 1 undergoes an $\mathrm{N}_{\mathrm{py}}-\mathrm{CH}_{3}$ bond activation process instead and affords complex $\mathbf{4 a}$ comprising a tridentate triazolylidene ligand with a chelating pyridine and imine donor group. ${ }^{[11]}$ Formally, complex $\mathbf{4 a}$ is the product of a methylene shift from the pyridinium fragment to the benzyl group, followed by insertion of a MeCN molecule. Support for solvent activation ${ }^{[12]}$ was obtained by carrying out the reaction in benzonitrile $(\mathrm{PhCN})$ instead of $\mathrm{MeCN}$, which yielded complex $\mathbf{4 b}$.

In solution, complexes $\mathbf{4 a}$ and $\mathbf{4 b}$ each display two characteristic $\mathrm{AB}$ resonance patterns for the two pairs of benzylic protons $\left({ }^{2} J_{\mathrm{HH}}\right.$ 14.1 and $12.9 \mathrm{~Hz}$, respectively, in $\mathbf{4 a}$ ), which are in a rigidly fixed geometry due to the tridentate bonding of the ligand. The iminebound proton appears at slightly lower field in $\mathbf{4 a}\left(\delta_{\mathrm{H}} 10.58\right)$ than in 4b $\left(\delta_{\mathrm{H}} 9.85\right)$. In the ${ }^{13} \mathrm{C}$ NMR spectrum, the $\mathrm{N}_{\text {imine }}$-bound carbon is observed at $190 \mathrm{ppm}$. Most diagnostically, IR spectroscopy revealed a stretch vibration at $v_{\mathrm{C}=\mathrm{N}}=1635( \pm 1) \mathrm{cm}^{-1}$.

The connectivity pattern was confirmed by single crystal X-ray diffraction studies on $\mathbf{4 a}$ and $\mathbf{4 b}$ (Fig. 1). The NCN-tridentate ligand may be considered as facially coordinating pincer ligand. ${ }^{[13]}$ The bond angles of the 5-membered metalacycle comprising the pyridine and the triazolylidene unit is acute and indicates some strain $\left(\mathrm{C}_{\mathrm{trz}}-\mathrm{Ir}-\mathrm{N}_{\mathrm{py}} 75^{\circ}\right)$, while the 9-membered metalacycle is considerably more flexible and adopts a coordination mode close to ideal for pseudo-octahedral iridium(III) complexes $\left(\mathrm{C}_{\mathrm{trz}}-\mathrm{Ir}-\mathrm{N}_{\mathrm{imine}}\right.$ $\left.85-90^{\circ}\right)$. The higher strain is also reflected in the $0.07-0.09 \AA$ 
longer $\operatorname{Ir}-\mathrm{N}_{\mathrm{py}}$ bond in both complexes when compared to the corresponding $\mathrm{Ir}-\mathrm{N}_{\mathrm{imine}}$ bond.
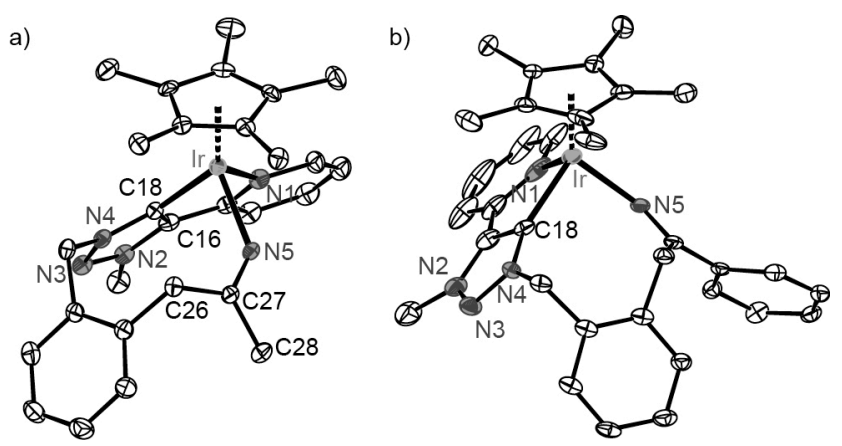

Figure 1. Ortep representations of complexes $4 a$ (a; $50 \%$ probability) and $\mathbf{4 b}$ (b; $30 \%$ probability). Solvent molecules, OTf anions and hydrogen atoms omitted for clarity; selected bond lengths $(\AA)$ and angles $\left({ }^{\circ}\right.$ ) for complexes 4a / 4b: Ir-C18 2.044(2) / 2.01(7), Ir-N1 2.151(2) / 2.159(7), Ir-N5 2.085(2) / 2.067(6); C18-Ir-N1 76.34(9) / 75.5(3), C18-Ir-N5 84.82(9) / 89.6(2), N1-Ir-N5 84.05(8) / 85.5(2).

Mechanistic details of this $\mathrm{C}-\mathrm{N}$ bond breaking and multiple $\mathrm{C}-$ $\mathrm{C}$ bond making process were investigated by isotope labeling studies. When using compound 1 with a ${ }^{13} \mathrm{C}$-labeled methyl group at $\mathrm{N}_{\text {pyr }}\left(1^{*}\right)^{[11]}$ under standard reaction conditions, complex $\mathbf{4 a}$ * was produced, which contained the ${ }^{13} \mathrm{C}$ nucleus exclusively in the benzylic position between the aryl and the imine unit. Selective ${ }^{13} \mathrm{C}$ labeling of $\mathbf{4 a}^{*}$ was confirmed by the split of the resonance due to the two benzylic protons into two doublets of doublets $\left(\delta_{\mathrm{H}} 4.27,{ }^{1} J_{\mathrm{CH}}\right.$ $=128 \mathrm{~Hz},{ }^{2} J_{\mathrm{HH}}=12.9 \mathrm{~Hz}$ ), and by the doublet resonance for the $\mathrm{NH}$ proton $\left({ }^{3} J_{\mathrm{CH}}=9 \mathrm{~Hz}\right)$. Similarly, all ${ }^{13} \mathrm{C}$ NMR signals due to the phenyl group and the $\mathrm{C}=\mathrm{N}$ functionality appear as doublets as a consequence of their coupling to the benzylic ${ }^{13} \mathrm{C}$ nucleus (e.g., $\delta_{\mathrm{C}=\mathrm{N}}$ 192.05 with ${ }^{1} J_{\mathrm{CC}}=43.1 \mathrm{~Hz}$ ). No traces of unlabeled benzylic carbon were detected, indicating a selective transfer of the $\mathrm{N}_{\text {pyr }}{ }^{-}$ bound carbon to the phenyl ring of the benzyl substituent.

Deuterium labeling of $\mathbf{1}$ at both $\mathrm{N}_{\text {pyr }}$ and $\mathrm{N}_{\text {trz }}$ by using $\mathrm{CD}_{3} \mathrm{OTf}$ as methylating agent gave $\mathbf{1}-\mathbf{D}_{\mathbf{6}}$. Reaction of this partially deuterated precursor with $\left[\mathrm{Ir}\left(\mathrm{Cp}^{*}\right) \mathrm{Cl}_{2}\right]_{2}$ in $\mathrm{CH}_{3} \mathrm{CN}$ under standard conditions gave 4a with only little D-incorporation. The ${ }^{2} \mathrm{H}$ NMR spectrum revealed $17 \%$ deuterium in the benzylic position as compared to the triazole-bound $\mathrm{N}_{\mathrm{trz}}-\mathrm{CD}_{3}$ group, yet no deuterium incorporation in the terminal $\mathrm{CH}_{3}$ group attached to the imine. The corresponding ${ }^{1} \mathrm{H}$ NMR spectrum confirmed these measurements, indicating no $\mathrm{N}_{\mathrm{trz}}$ $\mathrm{CH}_{3}$ residues and a benzylic proton integration of approximately $80 \%$. The inverse labeling, i.e. starting from the protio ligand precursor 1 and performing the reaction in $\mathrm{CD}_{3} \mathrm{CN}$ gave complex 4a- $\mathbf{D}_{5}$ with essentially complete deuteration at the terminal methyl group bound to the imine, and approximately $60( \pm 10) \%$ deuterium incorporation into the benzylic position. While these results do not allow for determining whether a methyl or a methylene group is transferred, they clearly indicate solvent-mediated isotope scrambling during the transfer process. No such scrambling at the methylene group interlinking the aryl and the triazole heterocycle or at the $\mathrm{N}_{\text {trz }}$-bound methyl group was observed. ${ }^{[14]}$ Hence, isotope exchange in the starting material seems unlikely. Similarly, exchange processes after the formation of $\mathbf{4}$ at only one of the two available benzylic positions is not supported.

When the reaction was stopped before completion, a variety of intermediates were detected. Thus after $2 \mathrm{~h}$, a hydride-containing intermediate was observed $\left(\delta_{\mathrm{H}}-14.28 \mathrm{ppm}, \mathrm{Cp} *\right.$ protons appear as doublet with $J_{\mathrm{HH}}=0.8 \mathrm{~Hz}$ ). Separation of the product mixture at this stage failed to give the hydride species in pure form. However, two species were isolated that were assigned to $\mathbf{B}$ and $\mathbf{B}^{\prime}$ along with minor quantities of $\mathbf{4 a}$ (Scheme 3 ). These products are present in a 1:0.7 ratio, irrespective of the reaction time $(2-16 \mathrm{~h})$ or the reaction temperature $\left(25-85^{\circ} \mathrm{C}\right)$, pointing to a thermodynamically controlled distribution. The two species are similar according to their ${ }^{1} \mathrm{H}$ NMR spectrum, both containing four pyridyl signals, two methyl groups (for $\mathrm{N}_{\mathrm{py}}-\mathrm{CH}_{3}$ and $\mathrm{N}_{\mathrm{trz}}-\mathrm{CH}_{3}$ ), and the benzylic protons split into an AB signal. ${ }^{[15]}$ Most diagnostically, both compounds contain only four phenyl protons appearing as two doublets and two doublets of doublets, which suggests orthometalation via $\mathrm{C}_{\text {phenyl }}-\mathrm{H}$ bond activation of the benzyl group. The major difference between the two species consists in the chemical shift of the $\mathrm{N}_{\mathrm{pyr}}-\mathrm{CH}_{3}$ group $\left(\delta_{\mathrm{H}}\right.$ 4.37 vs 3.92) and the meta-positioned pyridinium proton $(\mathrm{C} 3-\mathrm{H}$ at $\delta_{\mathrm{H}} 8.08 v s 8.33$ ). These differences concur with the presence of two rotamers comprising the $\mathrm{N}_{\mathrm{py}}-\mathrm{CH}_{3}$ group either pointing towards (B) or away from the monodentate NCMe ligand at iridium (B'). Nuclear Overhauser experiments indicate an anti conformation of the two $\mathrm{N}-\mathrm{CH}_{3}$ groups for the major isomer. ${ }^{[16]}$ These cyclometalated products were also obtained from 1 and $\left[\mathrm{IrCp}^{*} \mathrm{Cl}_{2}\right]_{2}$ with $\mathrm{AgOAc}$ only, i.e. in the absence of $\mathrm{Ag}_{2} \mathrm{O}$. In $\mathrm{CH}_{2} \mathrm{Cl}_{2}$ or in the solid state these rotamers $\mathbf{B}$ and $\mathbf{B}$ ' smoothly and spontaneously interconvert at room temperature to the ylide $\mathbf{3}$ exclusively. In $\mathrm{MeCN}$, the stability of the intermediates $\mathbf{B}$ and $\mathbf{B}$ ' is greatly enhanced as $\mathrm{C}-\mathrm{H}$ bond activation and ylide formation is only induced after several days at reflux temperature, indicating that $\mathrm{NCMe}$ displacement from $\mathbf{B}$ is essential to form complex 3. The ylide complex $\mathbf{3}$ is stable when heated in $\mathrm{MeCN}$ in the presence of $\mathrm{OAc}^{-}$. In contrast, the carbene intermediate $\mathbf{B}$ and complex $\mathbf{2}$ undergo methylene transfer under these conditions, thus gradually generating $\mathbf{4 a}$.

A tentative mechanism that is compliant with these observations is depicted in Scheme 3. Intermediate $\mathbf{A}$ has been observed previously ${ }^{[10]}$ and may be formed via in-situ transmetalation or by iridium-mediated $\mathrm{C}-\mathrm{H}$ activation, which would rationalize the traces of iridium-hydride species observed. Subsequent cyclometalation, probably $\mathrm{OAc}^{-}$assisted ${ }^{[17]}$ or via oxidative addition, ${ }^{[18]}$ generates a mixture of the $C, C$-bidentate complex $\mathbf{B}$ and $\mathbf{B}$ '. Upon exchange of the $\mathrm{MeCN}$ ligand in $\mathbf{B}$ by acetate, concerted and supposedly ratelimiting activation of the $\mathrm{C}-\mathrm{H}$ bond and cleavage of the $\mathrm{N}_{\mathrm{py}}-\mathrm{C}$ bond ensues $(\mathbf{C}),{ }^{[9]}$ thus producing a carbene species (speculatively represented as D) which may be susceptible to protonation and solvent-mediated H/D exchange. ${ }^{[19]}$ The interplay of acetate and iridium in mediating the proton abstraction and $\mathrm{N}_{\mathrm{py}}-\mathrm{C}$ bond activation seems most critical to this methyl transfer process. Methylene insertion into the $\mathrm{Ir}-\mathrm{C}_{\text {aryl }}$ bond, followed by activation of a coordinated solvent molecule via nucleophilic addition of the anionic benzyl group is postulated to generate the nine-membered metalacycle in 4. Albeit tentative, this mechanism takes into consideration that acetate is essential for the reaction to occur, and it allows the formation of the ylide $\mathbf{3}$ from the intermediates $\mathbf{B}$ and B' to be rationalized in the absence of acetate. The transfer of the carbon is selective, while H/D scrambling with the solvent may occur either at the carbene intermediate $\mathbf{D}$ or before protonation of the imide ligand in the conversion of $\mathbf{E}$ to $\mathbf{4}$. Due to the fast proton exchange at acetate, the mechanism also provides a rationale for the fact that none of the deuterium labeling experiments resulted in Dincorporation at the imine position.

In agreement with the proposed model, the methylene transfer process is suppressed when the precursor $\mathbf{1}$ contains a fluorinated benzyl group $\left(\mathrm{CH}_{2} \mathrm{C}_{6} \mathrm{~F}_{5}\right)$. No products similar to 4 were observed, 


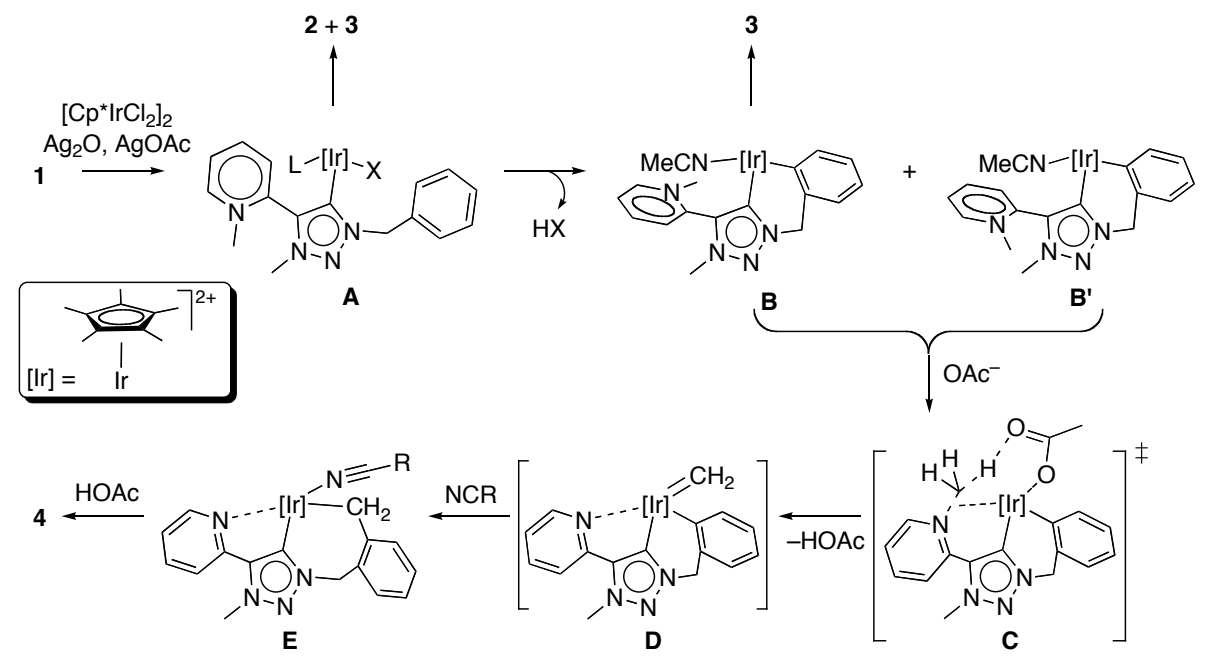

Scheme 3. Proposed mechanism for the iridium-mediated methylene transfer (X probably OTf, NCMe with non-coordinating OTf, or $\mathrm{Cl}$ ).

and instead, only pyridinium $\mathrm{C}-\mathrm{H}$ bond activation took place to give $\mathrm{C}_{6} \mathrm{~F}_{5}$-containing analogues of $\mathbf{2}$ and $\mathbf{3}$. Likewise, substitution of the benzylic group in $\mathbf{1}$ with a phenyl unit suppressed the methylene group transfer and afforded a bidentate cyclometalated product resulting from $\mathrm{C}_{\text {phenyl }}-\mathrm{H}$ bond activation reminiscent of $\mathbf{B} .^{[20]}$ Apparently, the steric flexibility of the benzyl group promotes the carbon transfer while phenyl coordination induces sufficient constraints to prevent the pyridinium ring from approaching the iridium center. Attempts to expand the reaction towards the transfer of different alkyl groups were unsuccessful. When using the ethyl-pyridinium analogue of $\mathbf{1}$, a complicated mixture of products formed that was inseparable in our hands, yet the crude product mixture showed no signals that might indicate the migration of the ethyl group from the pyridinium fragment.

Complex 4a is stable under neutral conditions and undergoes only incomplete $\mathrm{N}-\mathrm{H}$ to $\mathrm{N}-\mathrm{D}$ exchange in the presence of $\mathrm{D}_{2} \mathrm{O}$ even after several days. In acidic media (methanolic $\mathrm{HCl}$ ), rapid dissociation of the imine donor group and Schiff base reactivity was observed, resulting in the formation of complex 5 featuring a noncoordinated ketone (Fig. 2). No trace of $\mathrm{H}_{2}$ formation was observed. Complex $\mathbf{5}$ is characterized by a diagnostic IR absorption at $v_{\mathrm{C}=\mathrm{O}}=$ $1715 \mathrm{~cm}^{-1}$ for the non-coordinating carbonyl group. In the ${ }^{1} \mathrm{H}$ NMR spectrum the benzylic group adjacent to the triazolylidene ligand appears coincidentally as a singlet while the $\mathrm{CH}_{2}$ protons $\alpha$ to the carbonyl unit are split into an $\mathrm{AB}$ pattern $\left({ }^{2} J_{\mathrm{HH}} 17.5 \mathrm{~Hz}\right) .{ }^{[21]}$

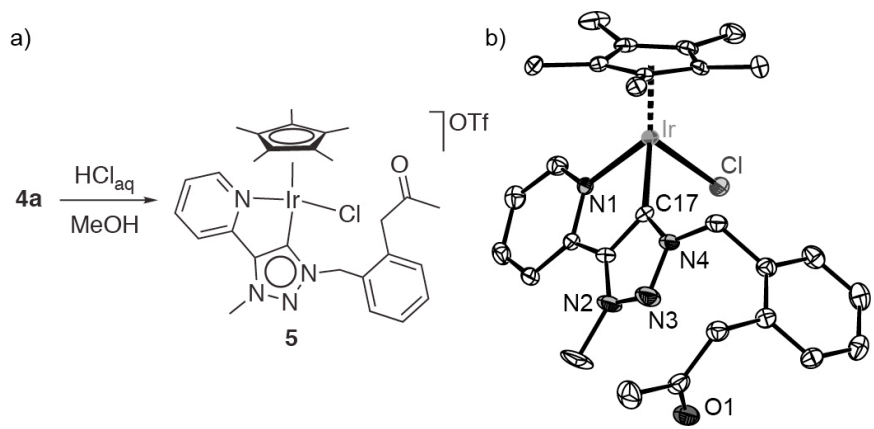

Figure 2. Synthesis (a) and ORTEP representation of 5 (b; $50 \%$ probability, OTf anion and hydrogen atoms omitted for clarity); Selected bond lengths $(\AA \AA)$ and angles $\left(^{\circ}\right)$ : Ir-C17 2.021(3), Ir-N1 2.130(2), Ir-Cl 2.4089(7); C17-Ir-N1 76.45(11).
In conclusion, we have observed an iridium-mediated, selective methylene transfer from a pyridinium unit to an unfunctionalized aryl carbon. Pyridinium demethylation is of great relevance, for example in the regeneration of mutated carcinogenic DNA. Most of the elementary steps of the observed transfer reaction have precedents: the $\mathrm{N}-\mathrm{C}$ bond activation in $\mathrm{N}-$ heterocyclic carbene ruthenium complexes, ${ }^{[9]}$ the $\mathrm{C}_{\text {aryl }}-\mathrm{H}$ bond activation and subsequent $\mathrm{C}\left(\mathrm{sp}^{2}\right)-\mathrm{C}\left(\mathrm{sp}^{3}\right)$ bond formation in the metal-catalyzed crosscoupling of unfunctionalized arenes, ${ }^{[1 e, f]}$ and nitrile activation in recent metalmediated reactions. ${ }^{[12]}$ Combining these processes in a single transformation provides a first functional model of methyltransferase and opens new avenues for organic functionalizations.

Received: ((will be filled in by the editorial staff))

Published online on ((will be filled in by the editorial staff))

Keywords: methylene transfer $\cdot$ iridium $\cdot$ pyridinium $\cdot$ methyl transferase $\cdot$ functional analogue

[1] a) G. Dyker, Angew. Chem. Int. Ed. 1999, 38, 1698; b) F. Kakiuchi, S. Murai, Top. Organomet. Chem. 1999, 3, 47; c) R. H. Crabtree, Dalton Trans. 2001, 2437; d) J. E. Bercaw, J. A. Labinger, Nature 2002, 417, 507; e) L.-C. Campeau, K. Fagnou, Chem. Commun. 2006, 1253; f) D. Alberico, M. E. Scott, M. Lautens, Chem. Rev. 2007, 107, 174; g) R. G. Bergman, Nature 2007, 446, 391; h) J. C. Lewis, R. G. Bergman, J. A. Ellman, Acc. Chem. Res. 2008, 41, 1013; i) A. Razin, A. D. Riggs, Science 1980, 210, 604; j) A. C. Mercer, M. D. Burkart, Nat. Chem. Biol. 2006, 2, 8; k) S. Bheemanaik, Y. V. R. Reddy, D. N. Rao, Biochem. J. 2006, 399, 177.

[2] a) G. L. Cantoni, J. Am. Chem. Soc. 1952, 74, 2942; b) D. Brown, J. Axelrod, R. Tomchick, Nature 1959, 183, 680; c) R. J. Roberts, Angew. Chem. 1994, 106, 1285; Angew. Chem. Int. Ed. 1994, 33, 1222; d) W. A. M. Loenen, Biochem. Soc. Trans. 2006, 34, 330; e) Y. Zhang, X. Zhu, A. T. Torelli, M. Lee, B. Dzikovski, R. M. Koralewski, E. Wang, J. Freed, C. Krebs, S. E. Ealick, H. Lin, Nature 2010, 465, 891 .

[3] a) Y.-T. Fanchiang, G. T. Bratt, H. P. C. Hogenkamp, Proc. Natl. Acad. Sci. USA 1984, 81, 2698; b) J. C. Evans, D. P. Huddler, M. T. Hilgers, G. Romanchuk, R. G. Matthews, M. L. Ludwig, Proc. Natl. Acad. Sci. USA 2004, 101, 3729.

[4] a) T. L. Grove, J. S. Benner, M. I. Radle, J. H. Ahlum, B. J. Landgraf, C. Krebs, S. J. Booker, Science 2011, 332, 604; b) F. Yan, D. G. Fujimori, Proc. Natl. Acad. Sci. USA 2011, 108, 3930.

[5] For selected examples, see: a) E. S. Lewis, S. Kukes, C. D. Slater, J. Am. Chem. Soc. 1980, 102, 1619; b) J. Rogers, D. A. Femec, R. L. Schowen, J. Am. Chem. Soc. 1982, 104, 3263; c) B. L. Iverson, P. B. Dervan, Proc. Natl. Acad. Sci. USA 1988, 85, 4615; d) B. A. McCortney, B. M. Jacobson, M. Vreeke, E. S. Lewis, J. Am. Chem. Soc. 1990, 112, 3554; e) R. J. Boyd, C. K. Kim, Z. Shi, N. Weinberg, S. Wolfe, J. Am. Chem. Soc. 1993, 115, 10147.

[6] a) M. Ehrlich, R. J.-H. Wang, Science 1981, 212, 1350; b) S. Kumar, X. Cheng, S. Klimasauskas, S. Mi, J. Posfai, R. J. Roberts, G. G. Wilson, Nucleic Acids Res. 1994, 22, 1.

[7] For a related palladium-mediated methyl transfer from a silane to an olefinic carbon, see: W. Rauf, J. M. Brown, Angew. Chem. Int. Ed. 2008, 47, 4228.

[8] For an approach using $\mathrm{MeOH}$ as $\mathrm{CH}_{3}$ source, see: A. Schnyder, T. Darbre, R. Keese, Angew. Chem. Int. Ed. 1998, 37, 1283. 
[9] a) S. Burling, M. F. Mahon, R. E. Powell, M. K. Whittlesey, J. M. J. Williams, J. Am. Chem. Soc. 2006, 128, 113702; b) L. J. L. Häller, M. J. Page, S. Erhardt, S. A. Macgregor, M. F. Mahon, M. A. Naser, A. Velez, M. K. Whittlesey, J. Am. Chem. Soc. 2010, 132, 18408; c) for a peculiar Ni-based system, see: S. Caddick, F. G. N. Cloke, P. B. Hitchoock, A. K. de K. Lewis, Angew. Chem. Int. Ed. 2004, 43, 5824.

[10] R. Lalrempuia, N. D. McDaniel, H. Müller-Bunz, S. Bernhard, M. Albrecht, Angew. Chem. Int. Ed. 2010, 49, 9765.

[11] See the supporting information for details.

[12] MeCN activation has precedents, see for examples: a) S. D. Ittel, C. A. Tolman, A. D. English, J. P. Jesson, J. Am. Chem. Soc. 1978, 100, 7577; b) D. Churchill, J. H. Shin, T. Hascall, J. M. Hahn, B. M. Bridgewater, G. Parkin, Organometallics 1999, 18, 2403; c) F. L. Taw, P. S. White, R. G. Bergman, M. Brookhart, J. Am. Chem. Soc. 2002, 124, 4192; d) N. A. Foley, T. B. Gunnoe, T. R. Cundari, P. D. Boyle, J. L. Petersen, Angew. Chem. Int. Ed. 2008, 47, 726; e) K. Niedermann, N. Früh, E. Vinogradova, M. Wiehn, A. Moreno, A. Togni, Angew. Chem. Int. Ed. 2001, 50, 1059.

[13] M. Albrecht, G. van Koten, Angew. Chem. Int. Ed. 2001, 40, 3750

[14] The absence of any significant D-incorporation at $\mathrm{Cp}^{*}$ does not suggest this fragment to be involved in the alkyl transfer mechanism.

[15] The AB sets are centered at 5.66 and $5.09 \mathrm{ppm}$ for $\mathbf{B}\left({ }^{2} J_{\mathrm{HH}}=17.8 \mathrm{~Hz}\right)$ and at 5.66 and $5.13 \mathrm{ppm}$ for $\mathbf{B}^{\prime}\left({ }^{2} J_{\mathrm{HH}}=14.6 \mathrm{~Hz}\right)$.

[16] Saturation of the major $\mathrm{N}_{\mathrm{py}}-\mathrm{CH}_{3}$ resonance at $3.92 \mathrm{ppm}$ revealed through-space interaction with the pyridine ortho proton only. The minor component $\mathbf{B}$ ' featured a positive nuclear Overhauser effect (nOe) upon saturation at the $\mathrm{N}_{\mathrm{py}}-\mathrm{CH}_{3}$ frequency $\left(\delta_{\mathrm{H}} 4.37\right)$ with the $\mathrm{N}_{\mathrm{trz}}-\mathrm{CH}_{3}$ group $\left(\delta_{\mathrm{H}} 4.04\right)$ and with the ortho $\mathrm{C}_{\mathrm{py}}-\mathrm{H}\left(\delta_{\mathrm{H}} 9.13\right)$, indicating a pseudo-syn arrangement of the two $\mathrm{N}-\mathrm{CH}_{3}$ groups.
Variable temperature NMR spectroscopy between -30 and $+70{ }^{\circ} \mathrm{C}$ did not provide any evidence for interconversion of the two species.

[17] a) D. L. Davies, S. M. A. Donald, O. Al-Duaij, S. A. Macgregor, M. Pölleth, J. Am. Chem. Soc. 2006, 128, 4210; b) Y. Boutadla, D. L. Davies, S. A. Macgregor, A. I. Poblador-Bahamonde, Dalton Trans. 2009, 5820; c) D. Balcells, E. Clot, O. Eisenstein, Chem. Rev. 2010, 110,749 .

[18] S. R. Klei, T. D. Tilley, R. G. Bergman, J. Am. Chem. Soc. 2000, 122, 1816.

[19] Due to the mesoionic character of the triazolylidene ligand, the proton does not need to be released through acetic acid formation and may, instead, be transiently transferred to the triazolylidene $\mathrm{C} 5$ position, see also: a) L. Bernet, R. Lalrempuia, W. Ghattas, H. Müller-Bunz, L. Vigara, A. Llobet, M. Albrecht, Chem. Commun. 2011, 47, 8058; b) A. Krüger, M. Albrecht, Aust. J. Chem. 2011, 65, in press (DOI: 10.1071/CH11265; c) F. E. Hahn, A. R. Naziruddin, A. Hepp, T. Pape, Organometallics 2010, 29, 5283; d) T. Kösterke, T. Pape, F. E. Hahn, J. Am. Chem. Soc. 2011, 133, 2112.

[20] a) K. Hiraki, K. Sugino, J. Organomet. Chem. 1980, 201, 469; b) G. D. Frey, J. Schütz, E. Herdtweck, W. A. Herrmann, Organometallics 2005, 24, 4416; c) S. H. Hong, A. Chlenov, M. W. Day, R. H. Grubbs, Angew. Chem. Int. Ed. 2007, 46, 5148; d) N. Stylianides, A. A. Danopoulos, D. Pugh, F. Hancock, A. Zanotti-Gerosa, Organometallics 2007, 26, 5627; e) Z. Liu, T. Zhang, M. Shi, Organometallics 2008, 27, 2668; f) G. L. Petretto, M. Wang, A. Zucca, J. P. Rourke, Dalton Trans. 2010, 397822 g) A. Poulain, D. Canseco-Gonzalez, R. Hynes-Roche, H. Müller-Bunz, O. Schuster, H. Stoeckli-Evans, A. Neels, M. Albrecht, Organometallics 2011, 30, 1021.

[21] Y. Boutadla, D. L. Davies, R. C. Jones, K. Singh, Chem. Eur. J. 2011, 17,3438 


\section{Methylene Transfer}

Ralte Lalrempuia, Helge Müller-Bunz, Martin Albrecht* Page -

Page<smiles>Cn1n[n+](Cc2ccccc2)cc1-c1cccc[n+]1C</smiles>

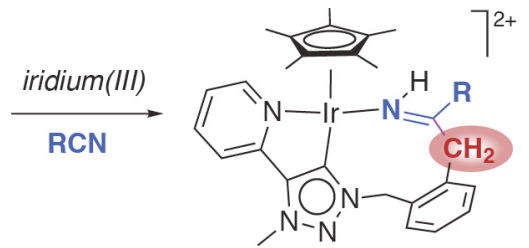

Methyltransferase Activity of an Iridium Center with Methylpyridinium as Methylene Source

Hop on - hop off: an iridium center transfers a methyl group from pyridinium to an aryl unit, using exclusively the pyridine-bound methyl group as a mild methylene source and accomplishing the cleavage of an unactivated $\mathrm{C}($ aryl $)-\mathrm{H}$ bond and nitrile solvent activation. The process is reminiscent of DNA methylation and entails the formation of two new $\mathrm{C}\left(\mathrm{sp}^{2}\right)-\mathrm{C}\left(\mathrm{sp}^{3}\right)$ bonds within the metal coordination sphere. 